Journal of Applied Pharmaceutical Science Vol. 5 (12), pp. 048-055, December, 2015

Available online at http://www.japsonline.com

DOI: $10.7324 / J A P S .2015 .501208$

ISSN 2231-3354 (cc) BY-NC-SA

\title{
Homology Modeling of DNA polymerases of Herpesviridae family and structure-based virtual screening for inhibitor identification
}

\author{
Subhashini Pandey ${ }^{1}$, Jitender Kumar ${ }^{1 *}$, N. K. Srivastava ${ }^{1}$, Som Dutt ${ }^{2}$ \\ ${ }^{1}$ Department of Chemical Engineering, Dr B R Ambedkar National Institute of Technology, Jalandhar, Jalandhar - 144 011, Punjab, India \\ ${ }^{2}$ Department of Biotechnology, Dr B.R. Ambedkar National Institute of Technology Jalandhar, Jalandhar - 144 011, Punjab, India.
}

\author{
ARTICLE INFO \\ Article history: \\ Received on: 04/08/2015 \\ Revised on: 16/09/2015 \\ Accepted on: 02/10/2015 \\ Available online: 27/12/2015 \\ Key words: \\ Herpesviridae Family, \\ Homology Modeling,Natural \\ Antiviral Compounds, \\ Virtual Screening, Docking,
}

\begin{abstract}
Human herpes viruses are responsible for the several transmitted infections in human. It is known that the DNA polymerase enzyme is one of the putative targets for herpes. Therefore, it is of interest to model all known DNA polymerases of Herpesviridae family. Here, all the DNA polymerases of Herpesviridae without any crystal structure were modeled using HHV-1 DNA polymerase as a template. Modeled structures were screened by ramachandran plot and Descrete Optimization of Protein Energy (DOPE) score. To find out multi-target inhibitor for Herpesviridae, 21 natural antiviral compounds were selected from literature and screened using Lipinski's rule of five. Binding pose of acyclovir with HHV-1 DNA polymerase was taken for the comparative docking study. Comparative binding analysis was done after settling of 120 and eight partial mono flexible protein-ligand docking sets for natural compounds and acyclovir, respectively. From the study it is found that alliin and gallic acid exhibit good binding affinity than acyclovir and other natural compounds. So, here we purpose that these two compounds can be potential candidates to inhibit Herpesviridae family.
\end{abstract}

\section{INTRODUCTION}

Herpes viruses are the leading cause of several transmitted infections in humans that are chronic, widespread and infectious during both its symptomatic and asymptomatic periods and are second only to influenza and cold viruses (Bernardino et al., 2008; Smith and Kennell, 1981). Infections caused by this family of viruses are endemic and sexual contact is a significant mode of transmission for herpes simplex virus 1 and 2 (HSV-1, HSV-2), human cytomegalovirus (HHV-5) and likely Karposi's sarcoma herpesvirus (HHV-8) (Anderson et al., 2014; Collins and Medveczky, 2002). The implication of Epstein-Barr viruses (HHV-4), Varicella Zoster Viruses (HHV-3) and Roseoloviruses (HHV-6 and HHV-7) as cofactors in human cancers and several skin infections create urgency for a better understanding of this complex (Morissette and Flamand, 2010; Yamamoto and Nakamura, 2000; Karatas et al., 2008). The drug target in structure-based drug design is mostly proteins that belong to the

* Corresponding Author

E-mail: jitender.dublad@gmail.com families of glycoprotein and DNA polymerase (Hudnall et al., 2004). A common therapy for herpes viral infections employs nucleoside analogs, such as acyclovir and valacyclovir which targets the viral DNA polymerase, essential for viral DNA replication (Prepens et al., 2007). This enzyme is an attractive target for the development of antiviral drugs, since the human herpes viruses share a common replication cycle in which the viral DNA polymerase acts in several points, being extremely important after the start of the beta-phase of viral replication cycle (VilibicCavlek et al., 2011).

Although a number of clinically useful drugs are available in the market for the treatment of human herpesvirus (HHV) infections but still there is no effective therapy for all the HHVs. The major limitations of the currently available antiherpetic drug therapy are drug resistance \& host toxicity (Gupta and Wald, 2006). Moreover, the narrow antiviral spectrum and resistance of DNA polymerases of Herpesviridae family, to these agents is an emerging problem for the disease management (Gottlieb et al., 2014). A better understanding of the target structures (DNA Polymerases) of Herpesviridae family will help to understand the development of new safe and effective broad spectrum antiherpetic 
drugs that fill an unmet need. In the present study, DNA polymerases of Herpesviridae family were modeled using homology modeling approach. The parameters used for the screening of the structure models were DOPE score and ramachandran (RC)plot analysis. Each model was processed through energy minimization step to achieve the accuracy and stability of the generated structures. A set of 21 compounds (which are known for their antiviral activity) were taken and initially screened by lipinski's rule of five. Fifteen screened compounds were further docked at the active site of the DNA polymerases of Herpesviridae family family. From the set of screened 15 compounds, alliin and gallic acid showed good binding affinity than the control acyclovir. These findings may provide useful insights for designing new potent multi-target inhibitors to fight against the infections of Herpesviridae family.

\section{MATERIALS AND METHODOLOGY}

\section{Sequence \& Phylogenetic Analysis}

The amino acid sequences of all the DNA polymerases of Herpesviridae family were deduced from the NCBI database (http://www.ncbi.nlm.nih.gov/protein). The multiple sequence alignment was carried out using ClustalX 2.1 for the identification of conserved residues throughout the Herpesviridae family. For further analysis among the Herpesviridae family, a phylogenetic tree was generated using maximum likelihood (ML) method of sea-view program. Bootstrap support was calculated from 100 replicates. To identify the suitable template in the Protein Data Bank (PDB) for the modeling of the target sequences, BLASTp was used with the default parameters.

\section{Homology Modeling and Screening of protein models}

Modeller9.9 was used to model DNA polymerases of Herpesviridae family by using HHV-1 DNA polymerase (PDB ID: 2GV9 at $2.68 \AA$ resolution) as template (Sali et al., 1995). Screening of ten generated models for each target was done with DOPE score and RC plot analysis. DOPE score is a reference state that corresponds to non-interacting atoms in a homogeneous sphere with the radius dependent on a sample original structure and can be computed using Modeller9.9 (Shenand Sali, 2006). PROCHECK was used to obtain RC plots to evaluate the backbone conformation by inspecting the Psi/Phi dihedral angles (Laskowski et al., 1993). The validation is done on the basis of various parameters such as lengths, angles and planarity of the peptide bonds, hydrogen bond geometry.

\section{Energy Minimization}

Gromacs 4.6.7 software package was used for the energy minimization studies of all seven screened models using Gromos53a6 force field. Pdb2gmx command was used to generate the topology of each model. An octahedron box was used for the solvation requirements with the distance of $1.2 \AA$ between solute and the box. Simple Point Charge Extended (SPC/E) water model was used in order to solvate the system. Sodium and Chloride ions were used to neutralize the system by replacing water molecules from the system. Finally, system was processed through energy minimization step using steepest-descent algorithm for 50,000 steps without any restraints. Periodic Boundary Conditions were used with rlist value of $0.9 \mathrm{~nm}$, rcoulomb $0.9 \mathrm{~nm}$ and rvdw value of $1.4 \mathrm{~nm}$.

\section{Ligand Selection}

In order to find the potent ligand molecules for Herpesviridae family, a set of 21 natural compounds (known antiviral activity), was taken from the literature. Lipinski's rule of five was used as the first filter to screen the drug-like compounds. The molecular structures were drawn by the Chemsketch (Li et al., 2004) and molecules were converted into protein data bank (.pdb) format from MDL (.mol) by using OpenBabel (O'Boyle et al., 2011).

\section{Molecular Docking \& Visualization}

Molecular docking of all the screened compounds was carried out using Autodock4.2 software package from The Scripps Research Institute (Morris et al.,2009). To get the docking interactions close to the experimental analysis, partial mono rigidflexible docking was used wherein target is kept rigid and binding site residues were allowed to move with flexible ligand molecule (Gupta et al.,2015). Initially, all the receptors and ligands are made to undergo a pre-optimization process using the autodock parameters like atom types, torsion modes and partial charges. A grid box of the size $42 \times 52 \times 42$ points covering the binding site residues was used throughout the docking analysis. A grid spacing of $0.450 \AA$ was used to ensure the standard grid spacing around the binding site.

Lamarckian Genetic Algorithm (LGA) was applied to find out the most favorable interactions. During each docking experiment, 100 runs were carried out with ten experiments for each ligand by keeping default parameters. The confirmation with most favorable free energy of binding and lowest root mean square deviation (RMSD) was selected. Visualization of the docked structure was performed on PyMol molecular graphics program, a comprehensive software package for rendering and animating 3Dstructures (Lilland Danielson, 2011).

\section{RESULTS AND DISCUSSIONS}

Binding mode of acyclovir and HHV-1 DNA polymerase has already been reported that explains acyclovir interacts with highly conserved KKKY motif present in the binding cleft to block the replication of viral DNA. Studies also state that the resistance to nucleoside inhibitors is a result of mutations in highly conserved region YGDTDS of HHV-1 DNA polymerase. The amino acid residues of YGDTDS region do not play any role in the catalysis but affects the binding cleft leading to the rejection of the nucleoside inhibitors. So, during the interaction analysis of any inhibitor it is very important to study both these signature elements of the HHV-1 DNA polymerase (Shenping et al., 2006; Baltz et al., 2009; Terrell and Coen, 2012). 


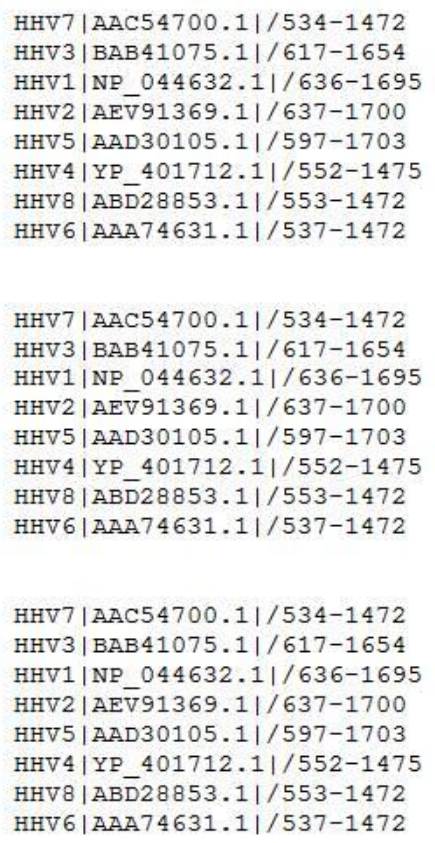

ILFPLILI TFIKLLLITRKKYIGVIY-GGKVLMRGVDLVRKNNCQFINDYARKLVELLLYDDTVSRAA 1035 TFTRLILIARRKYIGVIY-GGKMLIKGVDLVRKNNCAFINRTSRALVDLLFYDDTVSGAA 1051 TFTKLLLIA KKKYIGVIC-GGKMLIKGVDLVRKNNCAFINRTSRALVDLLFYDDTVSGAA 1055 VFVSLMMI IKRRYIGKVEGASGLSMKGVDLVRKTACEFVRGVTRDVLSLLFEDREVSEAA 1116 TFSCLMLITKRRYVGVLT-DGKTLMKGVELVRKTACKFVQTRCRRVLDLVLADARVREAA 1004 IFKCLLLITKKRYVGVLS-DDKVLMKGVDLIRKTACRFVQEKSSQVLDLILREPSVRAAA 1000 ILCPIILI KRRRYIGRQD-DSLLI FKGVDLVRKTSCDFVKGVVRDIVDLLFFDEEVQTAA 1004 


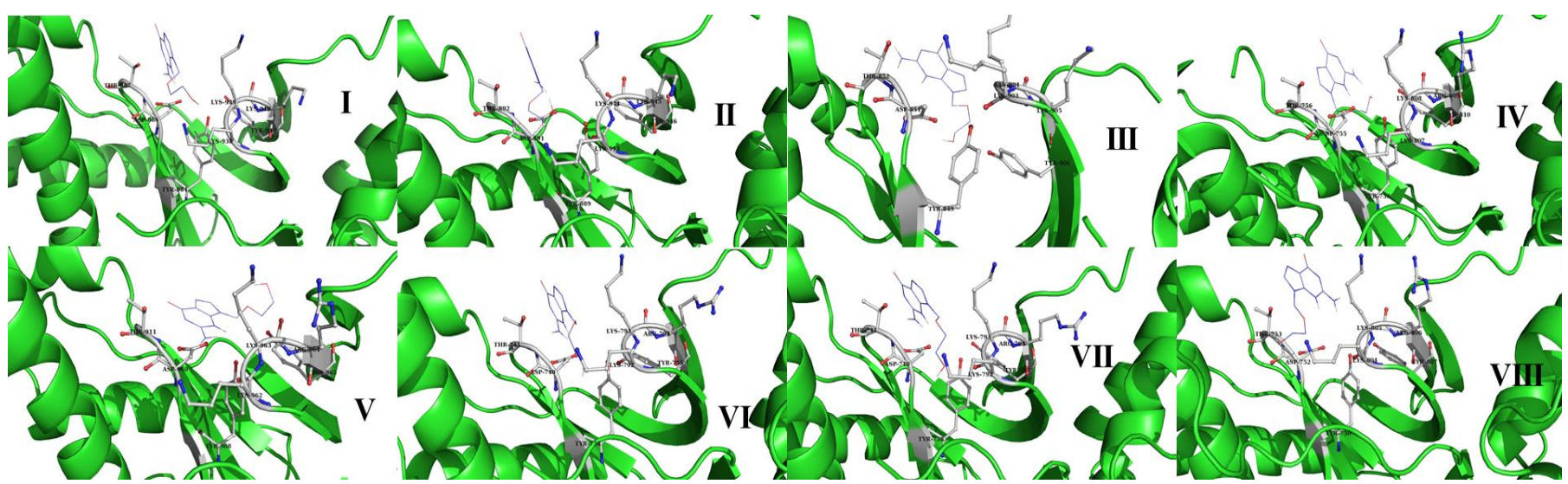

Fig. 3: Docking complexes of acyclovir with all the target proteins. Here acyclovir was shown in the wire form (violet color) whereas targets are shown in cartoon form (green color) with binding site residues as ball and stick form (white color).

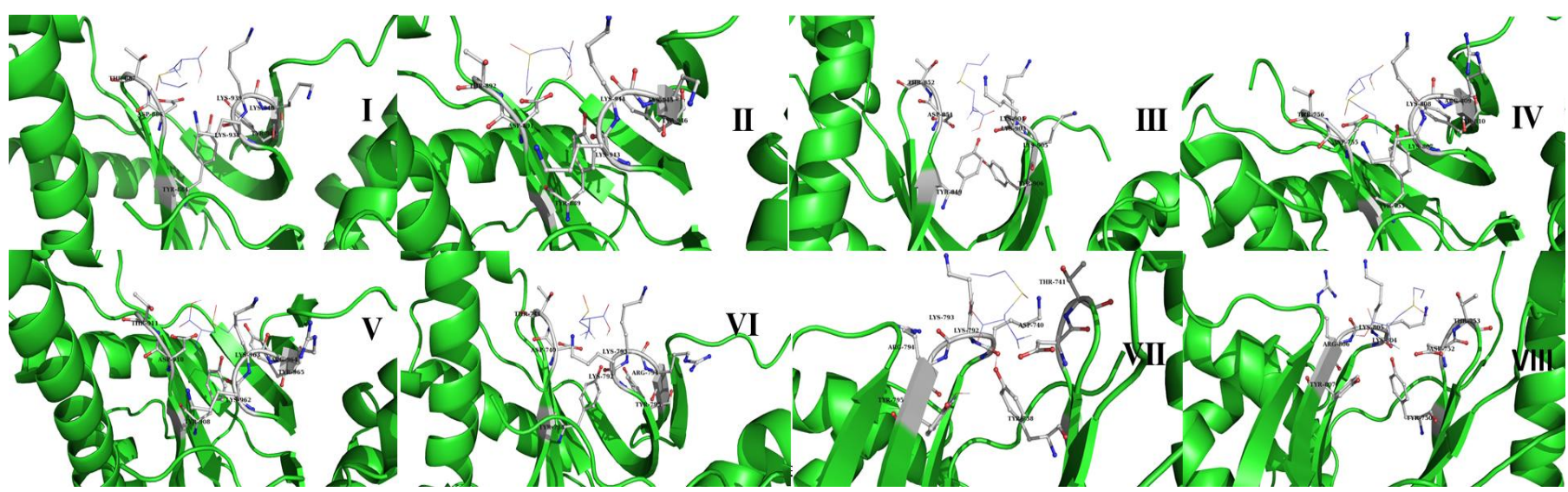

Fig. 4: Docking complexes of alliin with all the target proteins. Here alliin was shown in the wire form (violet color) whereas targets are shown in cartoon form (green color) with binding site residues as ball and stick form (white color).

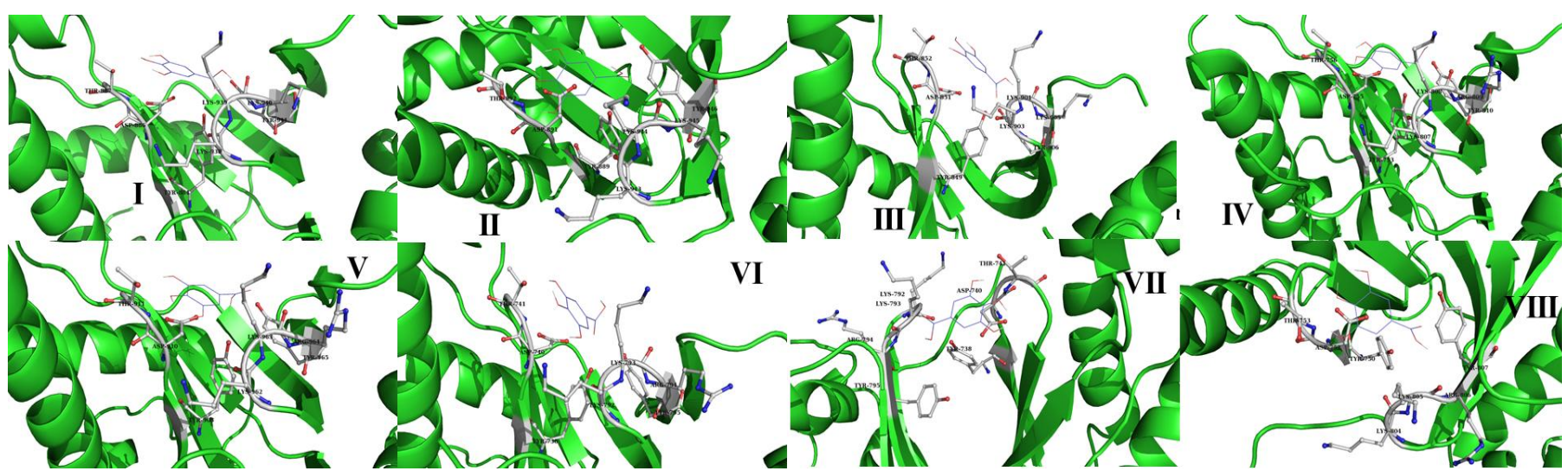

Fig. 5: Docking complexes of gallic acid with all the target proteins. Here gallic acid was shown in wire form (violet color) whereas targets are shown in cartoon form (green color) with binding site residues as ball and stick form (white color). 
Table 1: Ramachandran plot and DOPE scores for best DNA polymerase models of Herpesviridae family.

\begin{tabular}{llllll}
\hline Target & Core Region & Allowed Region & Gen. Allowed & Disallowed Region & DOPE Score \\
\hline HHV-2 & 88.6 & 10.0 & 1.0 & 0.4 & -127099.17188 \\
HHV-3 & 89.1 & 8.8 & 1.1 & 1.0 & -37365.89844 \\
HHV-4 & 93.5 & 6.2 & 0.3 & 0.0 & -37961.69531 \\
HHV-5 & 89.8 & 7.7 & 1.3 & 1.1 & -114385.992188 \\
HHV-6 & 88.6 & 9.3 & 1.5 & 0.5 & -111473.13281 \\
HHV-7 & 88.6 & 9.3 & 1.5 & 0.5 & -113489.45313 \\
HHV-8 & 88.6 & 9.5 & & 0.8 & -110305.17969 \\
\hline
\end{tabular}

Table 2: Lipinski's rule of five for natural antiviral compounds.

\begin{tabular}{|c|c|c|c|c|c|c|}
\hline Sr No & Compound Name & MI $\log P$ & MW & H Donors & H Acceptors & Violations \\
\hline 1. & Allicin & 2.064 & 162.279 & 1 & 0 & 0 \\
\hline 2. & Alliin & -3.393 & 177.225 & 4 & 3 & 0 \\
\hline 3. & Ajoene & 1.802 & 234.411 & 1 & 0 & 0 \\
\hline 4. & Nimbin & 3.552 & 540.609 & 9 & 0 & 1 \\
\hline 5. & Gallic Acid & 0.589 & 170.12 & 5 & 4 & 0 \\
\hline 6. & Gallocatechin & 1.077 & 306.27 & 7 & 6 & 1 \\
\hline 7. & Chicoric Acid & 1.269 & 474.374 & 12 & 6 & 2 \\
\hline 8. & Caftaric Acid & -0.608 & 312.23 & 9 & 5 & 0 \\
\hline 9. & Gingerol & 3.217 & 294.391 & 4 & 2 & 0 \\
\hline 10. & Shogaol & 4.348 & 276.376 & 3 & 1 & 0 \\
\hline 11. & Hydrastine & 2.831 & 383.4 & 7 & 0 & 0 \\
\hline 12. & Berberine & 0.196 & 336.367 & 5 & 0 & 0 \\
\hline 13. & Diosgenin & 5.932 & 414.63 & 3 & 1 & 1 \\
\hline 14. & Choline & -4.236 & 104.173 & 2 & 1 & 0 \\
\hline 15. & Harmaline & 2.505 & 214.268 & 3 & 1 & 0 \\
\hline 16. & Harmine & 2.626 & 212.252 & 3 & 1 & 0 \\
\hline 17. & Taraxerol & 8.023 & 426.729 & 1 & 1 & 1 \\
\hline 18. & Rosamarinic Acid & 1.626 & 360.318 & 8 & 5 & 0 \\
\hline
\end{tabular}

Table 3 : Docking results of acyclovir, alliin and gallic acid with all the target proteins of Herpesviridae family.

\begin{tabular}{|c|c|c|c|c|c|c|c|c|c|c|}
\hline \multirow{2}{*}{ Sr No } & \multirow{2}{*}{ Target } & \multicolumn{3}{|l|}{ Ligand Efficiency } & \multicolumn{3}{|c|}{ Binding Energy (kcal/mol) } & \multicolumn{3}{|c|}{ Inhibitory Constant (mM) } \\
\hline & & Acyclovir & Alliin & Gallic acid & Acyclovir & Alliin & Gallic acid & Acyclovir & Alliin & Gallic acid \\
\hline 1. & HHV-1 & -0.13 & -0.3 & -0.28 & -2.06 & -3.26 & -3.31 & 30.99 & 4.06 & 3.77 \\
\hline 2. & HHV-2 & -0.11 & -0.44 & -0.29 & -1.80 & -4.81 & -3.47 & 47.86 & 0.296 & 2.86 \\
\hline 3. & HHV-3 & -0.07 & -0.22 & -0.14 & -1.61 & -2.42 & -1.74 & 152.37 & 16.95 & 52.97 \\
\hline 4. & HHV-4 & -0.06 & -0.37 & -0.18 & -0.98 & -4.02 & -2.14 & 189.84 & 1.12 & 27.14 \\
\hline 5. & HHV-5 & -0.09 & -0.34 & -0.32 & -1.46 & -3.71 & -3.79 & 85.57 & 1.89 & 1.66 \\
\hline 6. & HHV-6 & -0.09 & -0.38 & -0.36 & -1.51 & -4.17 & -3.57 & 77.95 & 0.879 & 5.69 \\
\hline 7. & HHV-7 & -0.11 & -0.32 & -0.31 & -1.34 & -3.53 & -3.75 & 52.81 & 2.57 & 1.79 \\
\hline 8. & HHV-8 & -0.11 & -0.22 & -0.27 & -1.15 & -2.37 & -3.18 & 52.55 & 18.32 & 4.67 \\
\hline
\end{tabular}

The DNA polymerase sequences of all eight members of Herpesviridae family were aligned to find the homology (Figure 1). Interestingly, YGDTDS region was found highly conserved throughout the virus family, wherein KKKY motif, a lysine residue was found replaced by an arginine residue from KKKY motif. Transformation of the motif KKKY to KKRY explains the specificity of the positively charged binding pocket for the catalysis. Phylogenetic analysis of DNA polymerases of Herpesviridae family clearly follows the natural evolutionary classification which states that HHV-1, HHV-2 and HHV-3 are in alpha subfamily; HHV-5, HHV-6 and HHV-7 are in beta subfamily, whereas HHV-4 and HHV-8 are in gamma subfamily (Figure 2) (Gable et al., 2014). By homology modeling, ten models were generated for all the DNA polymerases of Herpesviridae family and the best models were selected on the basis of ramachandran plot analysis (High Core region and low disallowed region) and DOPE score analysis (low energy value) (Table 1). To increase the reliability of all the screened models, energy minimization was carried out in the presence of water molecules.
The focus of the present study is also to elucidate the action mechanism of naturally occurring antiviral compounds in inhibiting viral proteins of Herpesviridae family, as there is still a lack of clinically potential inhibitors. Hence, it would be a promising choice to block the Herpesviridae family with suitable inhibitors. Consequently, we have prepared a set of 21 natural antiviral compounds and screened on the basis of Lipinski's rule of five (Supplementary Table 1).

Virtual screening methods are routinely hand extensively used to reduce the cost and time of drug discovery process. The analysis of Lipinski's rule of five showed that nimbin, gallocatechin, chicoric acid, diosgenin, taraxerol and caryophyllene violates the rule. So these compounds were eliminated from docking process (Table 2). Acyclovir was considered as a control and docked with all eight DNA polymerases of the Herpesviridae family. For the 15 best screened compounds, 120 sets of partial mono flexible Protein-Ligand docking was carried outwith all eight DNA polymerase targets (Supplementary Tables 2 to 9). The binding pose of acyclovir at the active site of HHV-1 DNA polymerase was used to analyze the 
binding poses of docked natural antiviral compounds. Docking studies of acyclovir shows reduced binding affinity with DNA polymerases which has KKRY motif instead of KKKY motif (Figure 3). From the docking results, it was observed that alliin (Molecule 4) and gallic acid (Molecule 14) have good binding affinity compared to acyclovir and other natural antiviral compounds (Table 3). Both the compounds also qualify the Lipinski's filter as well as possess good molecular properties of drug likeness. Both the compounds were also found closely interacting with catalytic residues and well fitted into the binding cavity to generate stable complex (Figure 4 \& 5).

\section{CONCLUSION}

Recent studies showed increasing incidents of infections by Herpesviridae family, hence, there is a need to control Herpesviridae infection using suitable multi target inhibitors. For this, a better understanding of the structure of the target proteins is needed. So, here we documented the structure model of DNA polymerases of Herpesviridae family members (apart from $\mathrm{HHV}-1$ DNA polymerase). Binding poses of acyclovir with the DNA polymerases of Herpesviridae family were determined using partial rigid-flexible docking. The docking studies also contributed in the identification of alliin and gallic acid with good binding affinity to DNA polymerases of the Herpesviridae family in comparison to other natural compounds as well as their substrate acyclovir. So from all these observations we propose that alliin and gallic acid may block the Herpesviridae family and provide a significant basis for the antiherpetic drug development. However, in vitro and experimental evaluation is needed to consider these molecules as a suitable drug against the Herpesviridae family.

\section{REFERENCES}

Anderson NW, Buchan BW, Ledeboer NA. Light microscopy, culture, molecular, and serologic methods for detection of herpes simplex virus. Journal of Clinical Microbiology, 2014; 52(1): 2-8.

Baltz JL, Filman DJ, Ciustea M, Silverman JE, Lautenschlager CL, Coen DM, Ricciardi RP, Hogle JM. The crystal structure of PF-8, the DNA polymerase accessory subunit from Kaposi's sarcoma-associated herpesvirus. Journal of Virology, 2009; 83(23).

Bernardino AM, Castro HC, Frugulhetti IC, Loureiro NI, Azevedo AR, Pinheiro LC, Souza TM, Giongo V, Passamani F, Magalhaes UO, Albuquerque MG, Cabral LM, Rodrigues CR. SAR of a series of anti-HSV-1 acridone derivatives, and a rational acridone-based design of a new anti-HSV-1 3H-benzo[b]pyrazolo[3,4-h]-1,6 naphthyridine series.Bioorganic and Medicinal Chemistry, 2008; 16(1): $313-21$.

Collins CM, Medveczky PG. Genetic requirements for the episomal maintenance of oncogenic herpesvirus genomes. Advances in Cancer Research, 2002; 84: 155-74.

Gable JE, Lee GM, Jaishankar P, Hearn BR, Waddling CA, Renslo AR, Craik CS. Broad-spectrum allosteric inhibition of herpesvirus proteases. Biochemistry, 2014; 53(28): 4648-60.

Gottlieb SL, Low N, Newman LM, Bolan G, Kamb M, Broutet N. Toward global prevention of sexually transmitted infections (STIs): the need for STI vaccines. Vaccine, 2014; 32(14): 1527-35.

Gupta R, Wald A. Genital herpes: antiviral therapy for symptom relief and prevention of transmission. Expert Opinion on Pharmacotherapy, 2006; 7(6): 665-75.
Gupta S, Jadaun A, Kumar H, Raj U, Varadwaj PK, Rao AR. Exploration of new drug-like inhibitors for serine/threonine protein phosphatase 5 of Plasmodium falciparum: a docking and simulation study. Journal of biomolecular structure \& dynamics, 2015: 1-21.

Hudnall SD, Chen T, Tyring SK. Species identification of all eight human herpesviruses with a single nested PCR assay. Journal of Virological Methods, 2004; 116(1): 19-26.

Karatas H, Gurer G, Pinar A, Soylemezoglu F, Tezel GG, Hascelik G, Akalan N, Tuncer S, Ciger A, Saygi S. Investigation of HSV1, HSV-2, CMV, HHV-6 and HHV-8 DNA by real-time PCR in surgical resection materials of epilepsy patients with mesial temporal lobe sclerosis. Journal of the neurological sciences, 2008; 264(1-2): 151-6.

Laskowski RA, MacArthur MW, Moss DS, Thornton JM.PROCHECK- a program to check the stereochemical quality of protein structures. Journal of Applied Crystallography, 1993; 26: 283-291.

Li Z, Wan H, Shi Y, Ouyang P. Personal experience with four kinds of chemical structure drawing software: review on ChemDraw, ChemWindow, ISIS/Draw, and ChemSketch. $\mathbf{J}$ of chemical information and computer sciences, 2004; 44(5): 1886-90.

Lill MA, Danielson ML. Computer-aided drug design platform using PyMOL. Journal of computer-aided molecular design, 2011; 25(1): 13-9.

Liu S, Knafels JD, Chang JS, Waszak GA, Baldwin ET, Deibel MR Jr, Thomsen DR, Homa FL, Wells PA, Tory MC, Poorman RA, Gao H, Qiu X, Seddon AP. Crystal structure of the Herpes Simplex Virus 1 DNA Polymerase. The journal of biological chemistry, 2006; 281: 26.

Morissette G, Flamand L. Herpesviruses and chromosomal integration. Journal of virology, 2010; 84(23): 12100-9.

Morris GM, Huey R, Lindstrom W, Sanner MF, Belew RK, Goodsell DS, Olson AJ. Autodock4 and AutoDockTools4: automated docking with selective receptor flexibility. Journal of computational chemistry, 2009; 16: 2785-91.

O'Boyle NM, Banck M, James CA, Morley C, Vandermeersch T, Hutchison GR. Open Babel: An open chemical toolbox. Journal of cheminformatics, 2011; 3: 33.

Prepens S, Kreuzer KA, Leendertz F, Nitsche A, Ehlers B. Discovery of herpesviruses in multi-infected primates using locked nucleic acids (LNA) and a bigenic PCR approach.Virology Journal, 2007; 4: 84.

Sali A, Potterton L, Yuan F, van Vlijmen H, Karplus M. Evaluation of comparative protein modeling by MODELLER. Proteins, 1995; 23(3): 318-26.

Shen MY, Sali A. Statistical potential for assessment and prediction of protein structures. Protein science : a publication of the Protein Society, 2006; 15(11): 2507-24.

Smith KO, Kennell W. Differentiation of members of the human Herpesviridae family by radioimmunoassay. Infection and Immunity, 1981; 33(2): 491-7.

Terrell SL, Coen DM. The pre-NH(2)-terminal domain of the herpes simplex virus 1 DNA polymerase catalytic subunit is required for efficient viral replication. Journal of virology, 2012; 86(20): 11057-65.

Vilibic-Cavlek T, Kolaric B, Ljubin-Sternak S, MlinaricGalinovic G. Herpes simplex virus infection in the Croatian population.Scandinavian journal of infectious diseases, 2011; 43(11-12): 918-22.

Yamamoto T, Nakamura Y. A single tube PCR assay for simultaneous amplification of HSV-1/-2, VZV, CMV, HHV-6A/-6B, and EBV DNAs in cerebrospinal fluid from patients with virus-related neurological diseases. Journal of Neurovirology, 2000; 6(5): 410-17.

\section{How to cite this article:}

Pandey S, Kumar J, Srivastava NK, Dutt S. Homology Modeling of DNA polymerases of Herpesviridae family and structure-based virtual screening for inhibitor identification. J App Pharm Sci, 2015; 5 (12): 048-055. 


\section{Supplementary Tables}

Supplementary Table 1: List of selected Natural antiviral compounds.

\begin{tabular}{|c|c|c|c|}
\hline $\begin{array}{l}\text { Sr } \\
\text { no }\end{array}$ & Natural Source & $\begin{array}{c}\begin{array}{c}\text { Compound } \\
\text { Name }\end{array} \\
\end{array}$ & CID \\
\hline \multirow{3}{*}{1.} & \multirow{3}{*}{$\begin{array}{l}\text { Garlic } \\
\text { (Allium sativum) }\end{array}$} & Allicin & 65036 \\
\hline & & Alliin & 87310 \\
\hline & & Ajoene & 5386591 \\
\hline \multirow{3}{*}{2.} & \multirow{3}{*}{$\begin{array}{l}\text { Azadirachta } \\
\text {-indica }\end{array}$} & Nimbin & 108058 \\
\hline & & Gallic Acid & 370 \\
\hline & & Gallocatechin & 65084 \\
\hline \multirow{2}{*}{3.} & \multirow{2}{*}{ Echinacea } & Chicoric Acid & 5281764 \\
\hline & & Caftaric Acid & 53398694 \\
\hline \multirow{2}{*}{4.} & \multirow{2}{*}{$\begin{array}{l}\text { Ginger } \\
\text { (Zingiberofficinale) }\end{array}$} & Gingerol & 442793 \\
\hline & & Shogaol & 5281794 \\
\hline \multirow{2}{*}{5.} & \multirow{2}{*}{ Goldenseal } & Hydrastine & 1309 \\
\hline & & Berberine & 2353 \\
\hline \multirow{2}{*}{6.} & \multirow{2}{*}{ Methika (Fenugreek) } & Diosgenin & 99474 \\
\hline & & Choline & 305 \\
\hline \multirow{2}{*}{7.} & \multirow{2}{*}{ Peganumharmala } & Harmaline & 5280951 \\
\hline & & Harmine & 5280953 \\
\hline 8. & Clitoreaternatea & Taraxerol & 92097 \\
\hline \multirow{3}{*}{9.} & \multirow{3}{*}{ Ocimumsanctum } & Rosamarinic Acid & 5281792 \\
\hline & & Carvacrol & 10364 \\
\hline & & Caryophyllene & 5281515 \\
\hline 10. & Scrophularia-frutescense & Isovanillic Acid & 12575 \\
\hline
\end{tabular}

Supplementary Table 2: Docking results of all the screened compounds with HHV-1 target of Herpesviridae family

\begin{tabular}{cccc}
\hline $\begin{array}{c}\text { Sr } \\
\text { No Compound Name }\end{array}$ & $\begin{array}{c}\text { Ligand } \\
\text { efficiency }\end{array}$ & Binding affinity & $\begin{array}{c}\text { Inhibitory constant } \\
\text { (mM) }\end{array}$ \\
\hline 1. Acyclovir & -0.13 & -2.06 & 30.99 \\
3. Allicin & -0.22 & -1.95 & 37.29 \\
4. Alliin & -0.3 & -3.26 & 4.06 \\
5. Ajoene & -0.17 & -2.26 & 22.22 \\
6. Gallic Acid & -0.28 & -3.31 & 3.77 \\
7. Caftaric Acid & -0.09 & -2.02 & 32.92 \\
8. Gingerol & -0.02 & -0.46 & 461.99 \\
9. Shogaol & -0.07 & -1.5 & 79.0 \\
10. Hydrastine & -0.04 & -1.24 & 123.77 \\
11. Berberine & -0.08 & -1.94 & 37.59 \\
12. Choline & -0.15 & -1.06 & 167.09 \\
13. Harmaline & -0.16 & -2.52 & 14.24 \\
14. Harmine & -0.14 & -2.27 & 21.53 \\
15. Rosamarinic Acid & -0.05 & -1.3 & 111.39 \\
16. Carvacrol & -0.18 & -1.96 & 36.58 \\
17. Isovanillic Acid & -0.17 & -1.9 & 40.62 \\
\hline
\end{tabular}

Supplementary Table. 3: Docking results of all the screened compounds with HHV-2 target of Herpesviridae family

\begin{tabular}{llccc}
\hline Sr No Compound Name & $\begin{array}{c}\text { Ligand } \\
\text { efficiency }\end{array}$ & $\begin{array}{c}\text { Binding } \\
\text { affinity }\end{array}$ & $\begin{array}{c}\text { Inhibitory constant } \\
\text { (mM) }\end{array}$ \\
\hline 1. & Acyclovir & -0.11 & -1.8 & 47.86 \\
3. & Allicin & -0.07 & -0.68 & 356.76 \\
4. & Alliin & -0.44 & -4.81 & 0.296 \\
5. & Ajoene & -0.18 & -0.97 & 73.86 \\
6. & Gallic Acid & -0.29 & -3.47 & 2.86 \\
7. & Caftaric Acid & -0.19 & -3.2 & 38.92 \\
8. & Gingerol & -0.08 & -0.54 & 381.78 \\
9. & Shogaol & -0.10 & -2.5 & 72.0 \\
10. & Hydrastine & -0.08 & -1.84 & 137.63 \\
11. & Berberine & -0.12 & -2.23 & 44.56 \\
12. & Choline & -0.18 & -1.23 & 144.76 \\
13. & Harmaline & -0.13 & -2.12 & 16.56 \\
14. & Harmine & -0.17 & -2.54 & 23.87 \\
15. & Rosamarinic Acid & -0.08 & -1.7 & 123.78 \\
16. & Carvacrol & -0.12 & -1.45 & 42.65 \\
17. & Isovanillic Acid & $-0 . .15$ & -1.6 & 43.59 \\
\hline
\end{tabular}

Supplementary Table 4: Docking results of all the screened compounds with HHV-3 target of Herpesviridae family.

\begin{tabular}{clccc}
\hline $\begin{array}{c}\text { Sr } \\
\text { No }\end{array}$ & Compound Name & $\begin{array}{c}\text { Ligand } \\
\text { efficiency }\end{array}$ & $\begin{array}{c}\text { Binding } \\
\text { affinity }\end{array}$ & $\begin{array}{c}\text { Inhibitory } \\
\text { constant }\end{array}$ \\
\hline 1. & Acyclovir & -0.07 & -1.61 & 152.37 \\
3. & Allicin & -0.05 & -0.97 & 243.67 \\
4. & Alliin & -0.22 & -2.42 & 16.95 \\
5. & Ajoene & -0.04 & -0.86 & 74.47 \\
6. & Gallic Acid & -0.14 & -1.74 & 52.97 \\
7. & Caftaric Acid & -0.09 & -1.12 & 32.56 \\
8. & Gingerol & -0.06 & -0.68 & 232.45 \\
9. & Shogaol & -0.08 & -1.32 & 44.56 \\
10. & Hydrastine & -0.05 & -0.87 & 112.67 \\
11. & Berberine & -0.023 & -0.37 & 21.67 \\
12. & Choline & -0.11 & -1.56 & 65.56 \\
13. & Harmaline & -0.08 & -1.32 & 32.78 \\
14. & Harmine & -0.07 & -1.12 & 54.87 \\
15. & Rosamarinic Acid & -0.04 & -0.68 & 23.56 \\
16. & Carvacrol & -0.10 & -1.20 & 31.44 \\
17. & Isovanillic Acid & -0.11 & -1.3 & 28.67 \\
\hline
\end{tabular}

Supplementary Table 5: Docking results of all the screened compounds with HHV-4 target of Herpesviridae family

\begin{tabular}{llccc}
\hline $\begin{array}{c}\text { Sr } \\
\text { No }\end{array}$ & Compound Name & $\begin{array}{c}\text { Ligand } \\
\text { efficiency }\end{array}$ & Binding affinity & $\begin{array}{c}\text { Inhibitory } \\
\text { constant } \\
\text { (mM) }\end{array}$ \\
\hline 1. & Acyclovir & -0.06 & -0.98 & 189.84 \\
3. & Allicin & -0.06 & -1.12 & 112.53 \\
4. & Alliin & -0.37 & -4.02 & 1.12 \\
5. & Ajoene & -0.08 & -1.22 & 145.32 \\
6. & Gallic Acid & -0.18 & -2.14 & 27.14 \\
7. & Caftaric Acid & -0.11 & -1.43 & 22.41 \\
8. & Gingerol & -0.05 & -0.85 & 212.56 \\
9. & Shogaol & -0.06 & -0.76 & 23.66 \\
10. & Hydrastine & -0.07 & -1.29 & 122.33 \\
11. & Berberine & -0.033 & -0.45 & 27.45 \\
12. & Choline & -0.14 & -1.22 & 51.33 \\
13. & Harmaline & -0.05 & -1.12 & 34.55 \\
14. & Harmine & -0.08 & -1.87 & 44.45 \\
15. & Rosamarinic Acid & -0.05 & -0.68 & 23.56 \\
16. & Carvacrol & -0.09 & -1.20 & 31.44 \\
17. & Isovanillic Acid & -0.12 & -1.3 & 28.67 \\
\hline
\end{tabular}

Supplementary Table 6: Docking results of all the screened compounds with HHV-5 target of Herpesviridae family

\begin{tabular}{|c|c|c|c|c|}
\hline $\begin{array}{c}\mathrm{Sr} \\
\text { No }\end{array}$ & Compound Name & $\begin{array}{c}\text { Ligand } \\
\text { efficiency }\end{array}$ & $\begin{array}{l}\text { Binding } \\
\text { affinity }\end{array}$ & $\begin{array}{c}\text { Inhibitory } \\
\text { constant } \\
(\mathbf{m M})\end{array}$ \\
\hline & Acyclovir & -0.09 & -1.46 & 85.57 \\
\hline & Allicin & -0.66 & -1.12 & 22.61 \\
\hline & Alliin & -0.34 & -3.71 & 1.89 \\
\hline & Ajoene & -0.06 & -1.22 & 32.66 \\
\hline & Gallic Acid & -0.32 & -3.79 & 1.66 \\
\hline & Caftaric Acid & -0.09 & -1.53 & 114.55 \\
\hline & Gingerol & -0.07 & -1.81 & 123.7 \\
\hline & Shogaol & -0.11 & -2.21 & 112.66 \\
\hline & Hydrastine & -0.16 & -2.28 & 144.67 \\
\hline & Berberine & -0.08 & -0.89 & 44.63 \\
\hline & Choline & -0.22 & -2.22 & 1.73 \\
\hline 13. & Harmaline & -0.12 & -2.43 & 155.6 \\
\hline 14. & Harmine & -0.15 & -2.23 & 1.88 \\
\hline 15. & Rosamarinic Acid & -0.08 & -0.97 & 127.8 \\
\hline & Carvacrol & -0.14 & -2.12 & 76.9 \\
\hline 17. & Isovanillic Acid & -0.12 & -1.3 & 66.90 \\
\hline
\end{tabular}


Supplementary Table 7: Docking results of all the screened compounds with HHV-6 target of Herpesviridae family

\begin{tabular}{ccccc}
\hline Sr No & Compound Name & $\begin{array}{c}\text { Ligand } \\
\text { efficiency }\end{array}$ & $\begin{array}{c}\text { Binding } \\
\text { affinity }\end{array}$ & $\begin{array}{c}\text { Inhibitory } \\
\text { constant }\end{array}$ \\
\hline 1. & Acyclovir & -0.09 & -1.51 & $77.95(\mathrm{mM})$ \\
3. & Allicin & -0.09 & -1.36 & 44.63 \\
4. & Alliin & -0.38 & -4.17 & 0.8790 \\
5. & Ajoene & -0.16 & -1.78 & 64.87 \\
6. & Gallic Acid & -0.36 & -3.57 & 5.69 \\
7. & Caftaric Acid & -0.27 & -1.67 & 55.41 \\
8. & Gingerol & -0.15 & -0.85 & 113.55 \\
9. & Shogaol & -0.10 & -0.76 & 44.78 \\
10. & Hydrastine & -0.13 & -1.29 & 112.67 \\
11. & Berberine & -0.08 & -0.45 & 51.34 \\
12. & Choline & -0.23 & -1.22 & 70.67 \\
13. & Harmaline & -0.11 & -1.12 & 55.8 \\
14. & Harmine & -0.18 & -1.87 & 65.27 \\
15. & Rosamarinic Acid & -0.09 & -0.68 & 67.4 \\
16. & Carvacrol & -0.15 & -1.20 & 44.6 \\
17. & Isovanillic Acid & -0.17 & -1.3 & 38.9 \\
\hline
\end{tabular}

Supplementary Table 8: Docking results of all the screened compounds with HHV-7 target of Herpesviridae family

\begin{tabular}{|c|c|c|c|c|}
\hline $\begin{array}{l}\text { Sr } \\
\text { No }\end{array}$ & Compound Name & Ligand efficiency & $\begin{array}{l}\text { Binding } \\
\text { affinity }\end{array}$ & $\begin{array}{c}\text { Inhibitory } \\
\text { constant }\end{array}$ \\
\hline 1. & Acyclovir & -0.11 & -1.34 & 52.81 \\
\hline 3. & Allicin & -0.09 & -1.11 & 22.34 \\
\hline 4. & Alliin & -0.32 & -3.53 & 2.57 \\
\hline 5. & Ajoene & -0.13 & -0.85 & 32.44 \\
\hline 6. & Gallic Acid & -0.31 & -3.75 & 1.79 \\
\hline 7. & Caftaric Acid & -0.22 & -1.73 & 66.71 \\
\hline 8. & Gingerol & -0.16 & -0.97 & 117.61 \\
\hline 9. & Shogaol & -0.08 & -0.87 & 48.61 \\
\hline 10. & Hydrastine & -0.15 & -1.54 & 117.7 \\
\hline 11. & Berberine & -0.07 & -0.56 & 76.3 \\
\hline 12. & Choline & -0.27 & -1.34 & 99.7 \\
\hline 13. & Harmaline & -0.28 & -1.22 & 67.2 \\
\hline 14. & Harmine & -0.17 & -1.93 & 75.6 \\
\hline 15. & Rosamarinic Acid & -0.12 & -0.87 & 82.7 \\
\hline 16. & Carvacrol & -0.24 & -1.54 & 53.6 \\
\hline 17. & Isovanillic Acid & -0.27 & -1.8 & 55.7 \\
\hline
\end{tabular}

Supplementary Table 9: Docking results of all the screened compounds with HHV-8 target of Herpesviridae family

\begin{tabular}{clccc}
\hline $\begin{array}{c}\text { Sr } \\
\text { No }\end{array}$ & Compound Name & $\begin{array}{c}\text { Ligand } \\
\text { efficiency }\end{array}$ & $\begin{array}{c}\text { Binding } \\
\text { affinity }\end{array}$ & $\begin{array}{c}\text { Inhibitory } \\
\text { constant } \\
\text { (mM) }\end{array}$ \\
\hline 1. & Acyclovir & -0.11 & -1.15 & 52.55 \\
3. & Allicin & -0.06 & -0.76 & 212.33 \\
4. & Alliin & -0.22 & -2.37 & 18.32 \\
5. & Ajoene & -0.17 & $-2,12$ & 54.77 \\
6. & Gallic Acid & -0.27 & -3.18 & 4.67 \\
7. & Caftaric Acid & -0.19 & -1.73 & 78.91 \\
8. & Gingerol & -0.15 & -0.97 & 121.67 \\
9. & Shogaol & -0.09 & -0.87 & 63.21 \\
10. & Hydrastine & -0.17 & -1.54 & 121.7 \\
11. & Berberine & -0.10 & -0.67 & 86.7 \\
12. & Choline & -0.22 & -1.38 & 112.6 \\
13. & Harmaline & -0.18 & -1.41 & 76.2 \\
14. & Harmine & -0.19 & -1.66 & 87.6 \\
15. & Rosamarinic Acid & -0.17 & -0.91 & 92.8 \\
16. & Carvacrol & -0.23 & -1.42 & 77.8 \\
17. & Isovanillic Acid & -0.25 & -1.65 & 63.2 \\
\hline
\end{tabular}

